\title{
Corporate Capital Structure Changes during Financial Crisis: Case of Polish Companies
}

\author{
Elzbieta Wrońska-Bukalska \\ Maria Curie-Skłodowska-University, Poland \\ elzbieta.bukalska@umcs.lublin.pl \\ Kamil Mazurkiewicz \\ Maria Curie-Skłodowska-University, Poland \\ kamil.mazurkiewicz@poczta.umcs.lublin.pl
}

The paper is addressed to the subject of corporate capital structure (equity and debt relation) for Polish companies. The aim of the paper is to identify the changes in capital structure with regard to the recent financial crisis. The research hypothesis is that the leverage would decrease during crisis period and increase after crisis. In the paper the impact of financial crisis on capital structure was analysed on four sets of data: data for all companies of the whole economy, panel data of Polish listed companies, panel data of Polish listed companies with the lowest debt ratio in 2005 (panel A) and panel data of Polish listed companies with the highest debt ratio in 2005 (panel B). The descriptive statistics and the statistical testing of the differences were employed. The multivariate regression analysis was also employed to identify how different factors affect the capital structure. The main finding of the paper is that Polish companies generally did not change their capital structure during financial crisis time. This is especially true for the panel sample and panel B, while companies from panel A increase their debt ratio despite financial crisis.

Key Words: capital structure, profitability, tangibility, size, financial crisis

JEL Classification: G01, G32

https://doi.org/10.26493/1854-6935.16.19-35

\section{Introduction}

The financial crisis had impact on many aspects of economic activity. Banks not only were affected but also companies. One channel of crisis transferring from banks to companies was debt constraints. Banks tightened the conditions of granting bank loans. In addition, companies running business under difficult economic conditions with access that is more difficult to financing were impacted severely by financial crisis. The capital structure is one of the most important financial issues of corporate finance but also one of the financial aspect that was hit by financial crisis. 
The paper addresses the issue of capital structure during a financial crisis by analysing the capital structure of firms in Poland. Although Poland is perceived to be hit slightly by financial crisis there were some changes in corporate capital structure.

The aim of the paper is to find out what are the changes in capital structure of Polish companies over time, especially during and after the financial crisis of 2007-2009. The research problem is designed in the following question: how the capital structure changed during financial crisis. The hypothesis was developed assuming that during financial crisis, the leverage ratio decreased and after financial crisis, the leverage ratio increased to the pre-crisis level.

The justification of the research is that capital structure decisions are an important aspect of company running but there are just few studies referring to the problem of capital structure during a financial crisis in relation to a pre-crisis period. These studies are as follows: Fosberg (2012), Kahle and Stulz (2013), Iqbal and Kume (2014) and Demirguc-Kunt, MartinezPeria, and Tressel (2015), and these studies proves changes in capital structure during a financial crisis.

The paper contributes to the discussion on capital structure by including Polish financial crisis perspective. Broadening the analysis will help to have a better understanding of factors affecting financing decisions.

The impact of a financial crisis on capital structure was analysed on four sets of data: aggregated data for all companies of the whole economy, panel firm-level data of Polish listed companies, panel firm-level data of Polish listed companies with the lowest debt ratio in 2005 (panel A) and panel firm-level data of Polish listed companies with the highest debt ratio in 2005 (panel B). The descriptive statistics, the differences testing and regression analysis were employed.

The rest of the paper is organized as follows: the next section refers to the theoretical aspects of capital structure decisions, the third section to the problem of capital structure decisions during a financial crisis, the fourth section contains the description of the financial crisis in Poland, the fifth section the sources of data, the sixth section the description of methodology and the seventh section research findings; the conclusions are included in the eighth section.

\section{Capital Structure Theories and Capital Structure Determinants}

There are many static capital structure theories: the irrelevance theory of Modigliani and Miller (1958), Modigliani and Miller (1963) revision of 
their theory (including corporate income tax, and later on personal income tax), the trade-off theory (including agency problems and financial distress), the pecking order theory and the market timing theory. The theories give contradictory recommendation on how to design capital structures. The irrelevance theory of Modigliani and Miller assumes that capital structure has no impact on the company value and the company value is the same regardless capital structure. The revised theory of Modigliani and Miller assumes that the companies should use leverage (debt) as much as possible because it increases the value of the company. The trade-off theory of Kraus and Litzenberger (1973) assumes that there is optimal capital structure that minimizes the cost of capital and maximizes the company value. The optimal capital structure depends on the agency costs, bankruptcy costs and tax shield of interests.

The only approach that involves changes in capital structure is the pecking order theory and the market timing theory. The problem of changes in dynamic capital structure theories is solved with reference to the single company specific features. The pecking order theory of Myers and Majluf (1984) assumes that company should use internal sources of financing as the first, if they are insufficient and company has to gain external sources it should be debt and as the last source of financing it should be equity. The timing market theory of Baker and Wurgler (2002) assumes that the managers are aware of the situation on the financial market and if they think that the securities are overvalued, they would be gaining new capital by a new issue of securities; and if they think that the securities are undervalued they would buy them back.

There are a lot of research verifying the assumption and recommendations of all the capital structure theories. However, the problem of capital structure seems to be still not solved and it is not known which theory explains better the capital structure decisions (Myers 1983; Baker and Martin 2011, 12).

Some researchers look for the factors affecting capital structure (AlNajjar and Hussainey 2011; Rajan and Zingales 1995; Harris and Raviv 1999). Some of the most important identified factors affecting capital structure decisions are as follows (Bauer 2004; Titman and Wessels 1988; Korajczyk and Levy 2003; Cook and Tang 2010):

- Profitability - if the profitability is higher, the company might expect the positive effects of financial leverage (increase in ROE), but the pecking order theory assumes that the higher profitability the 
more internal cash flow the company has and the lower demand for external funds and the lower debt is used.

- Tangibility - the more fixed and tangible assets the company has the more long-term capital it needs, but the more tangible asset might be used as collateral the more debt the company might get; the tangibility is connected with the industry the company operates because some industries need more fixed assets.

- Size - larger firms tend to be more diversified, to have lower cash flow volatility and better access to financial markets, so they are less likely to become financially distressed. This suggests that there may be a positive relationship between the company size and debt financing. However, since large firms communicate more with investors, the asymmetrical information problem should be decreased, and consequently they should rather issue shares than debt. Again, the exact impact of firms' size on capital structure is unclear.

A financial crisis generates some variations in future cash flows, volatility of earnings increases, downturn in profitability, which increases business risk. The crisis resulted in a lower optimism and higher uncertainty about economic recovery. This led to a decline in demand for products and services and resulted in a fall in debt and equity issuance. Financial crisis may impact the capital structure of firms through different channels. Financial crisis leads to decrease in profitability and in investment spending during a financial crisis. When operating cash flows, profitability, investment and business risk depend on current economic conditions, firms should adjust their capital structure decisions to an economies' business cycle phase. Risk is lower in an expansion than in a contraction, so the debt capacity of the firm is greater during economic prosperity (Hackbarth, Miao, and Morellecc 2006; Mostarac and Petrovic 2013). The financial crisis have impact on the factors affecting capital structure and these factors have different impact on capital structure decisions before, during and after financial crisis. The crisis affected firms' ability to get financing, which is one of the key determinants of the operating activities (short and long-term). A financial crisis affected internal financing (especially net profit) and external financing (especially bank loans).

\section{Financial Crisis and Capital Structure: Literature Review}

During a crisis, as uncertainty and risk rise and expected returns decline, both lenders and borrowers become reluctant to lock-in capital in long- 
term investments (Demirguc-Kunt, Martinez-Peria, and Tressel 2015). There is some research on changes in leverage ratio during a financial crisis.

Graham, Leary, and Roberts (2014) studied the impact of the recent financial crisis on the capital structure decision of UK, French and German firms. The results show that overall leverage ratios increase from precrisis (2006 and 2007) to crisis years (2008 and 2009) and then decrease in the post-crisis years (2010 and 2011). The sample in their study consists of firms from three major European countries, i.e. the UK, France, and Germany over 2006-2011 period. The relevant data are extracted from Datastream. The initial sample is selected using the following criteria: firms are listed on the London Stock Exchange for UK, Euronext Paris for France, and the Frankfurt Stock Exchange for Germany; firms operate in non-financial and non-utility sectors. These restrictions produce final samples of 871 firms for the U K, 564 for France, and 392 for Germany. The study uses firm-year observations for the analysis and the analysis includes descriptive statistics and a multivariate regression analysis.

Kahle and Stulz (2013) studied changes in firm investment and financing policies during the crisis to investigate whether these changes are consistent with the view that a bank-lending shock or a credit supply shock - as opposed to a demand shock - is a first-order determinant of these policies, and whether the balance sheet multiplier made the impact of the crisis worse on levered firms. They find that net debt issuance increases during the first year of the crisis for most types of examined firms. Net equity issuance decreases during the crisis until April 2009. However, later, in the second year of the crisis, the need for external capital is weak and leads to a reduction in firms' leverage ratios. They use quarterly financial data and use cross-sectional variation in changes of ratios.

Pattani, Vera, and Wackett (2011) studied the role of public capital markets in relation to banking capital supply. They point out that only a small fraction of $U K$ companies issue public debt or equity as a form of external finance, but evidence suggests that the access to public capital markets allowed some companies to dampen the impact of the recent financial crisis, particularly the sharp reduction in the supply of bank credit. Corporate bond issuance enabled companies to switch away from bank loans. In addition, equity issuance allowed companies to reduce their leverage.

Fosberg (2012) shows that between 2006 and 2008 the financial crisis and the simultaneous recession caused sample firms to significant increase in debt ratios of Us firms over the pre-crisis period of 2006-2008 
followed by a gradual decline in debt levels by the end of 2010 (i.e. postcrisis period) to the pre-crisis level. He analysed data on global debt and equity offering from 2007 until 2010 and on capital structure. He used descriptive statistics and a multivariate regression analysis.

Iqbal and Kume (2014) examined the impact of the recent financial crisis on the capital structure decision of UK, French and German firms. The results show that overall leverage ratios increase from pre-crisis (2006 and 2007) to crisis (2008 and 2009) years and then decrease in the postcrisis (2010 and 2011) years. Both equity and debt levels change during the crisis and post-crisis years. The sample in the study consists of firms from three major European countries that are the U K, France, and Germany over 2006-2011 period. The relevant data are extracted from Datastream. They used samples of 871 firms for the U K, 564 for France, and 392 for Germany. They employed descriptive statistics and a multivariate regression analysis.

Demirguc-Kunt, Martinez-Peria, and Tressel (2015) used a data set covering about 277,000 firms across 79 countries over the period 20042011. They examined the evolution of firms' capital structure during the global financial crisis and its aftermath in 2010-2011. The study finds that firm leverage declined in advanced economies and developing countries, even in those countries that did not experience a crisis. They use descriptive statistics and multivariate regression analysis.

\section{Financial Crisis in Poland}

Poland faced a global financial crisis that started in the summer of 2007. However, contrary to many other European countries, Poland did not suffered heavily. That is why Poland was called 'a green island' (Polanski 2014). The Polish GDP growth against UE GDP growth is presented in figure 1. In the period of 2004-2008, Poland experienced high economic growth, with the average annual GDP growth amounting to $6 \%$ (as against $3 \%$ in the EU). In 2009, Poland was the only EU country to avoid recession (with the GDP growth of $1.6 \%$, while in the economy of the EU27 contracted by $4.5 \%$ ). However, the external conditions affected the Polish economy, leading to a significant slowdown in the rate of growth which was particularly evident in 2012, with the GDP growth amounting to $1.9 \%$. Therefore, the average annual rate of GDP growth in the period 2009-2012 slowed down to $2.9 \%$ (while the $\mathrm{EU}$ as a whole was in recession with the average annual GPD growth amounting to $-0.3 \%$ ) (OECD 2013). 


$$
8
$$

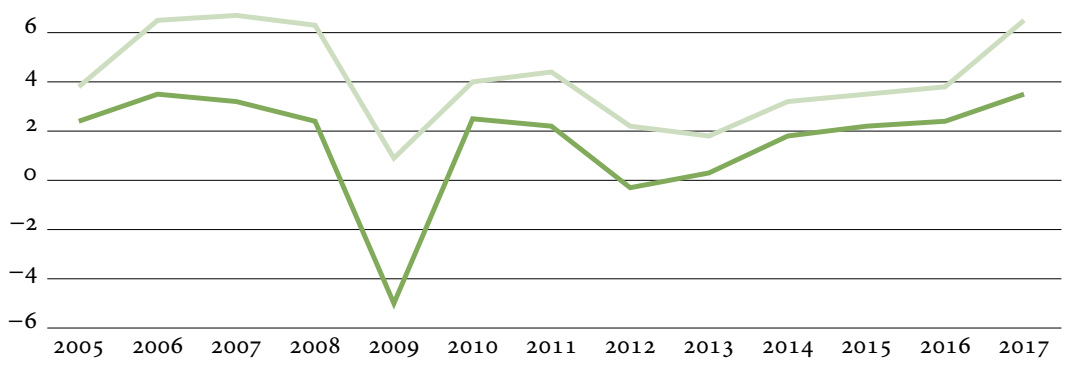

FIGURE 1 UE (dark) and Poland (light) GDP Growth (in percent) (based on data from https://pl.tradingeconomics.com)

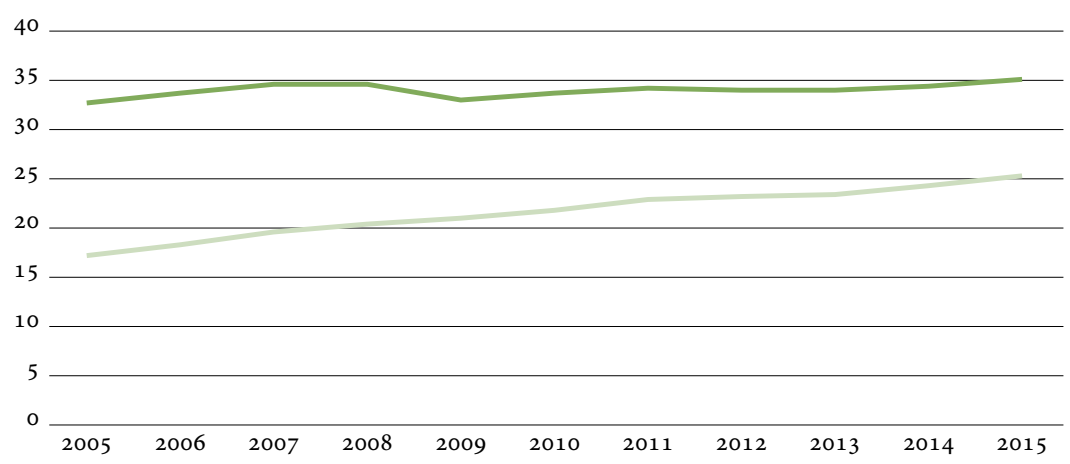

FIGURE 2 UE (Dark) and Poland (Light) GDP per Capita (in Euro)

(based on data from https://pl.tradingeconomics.com)

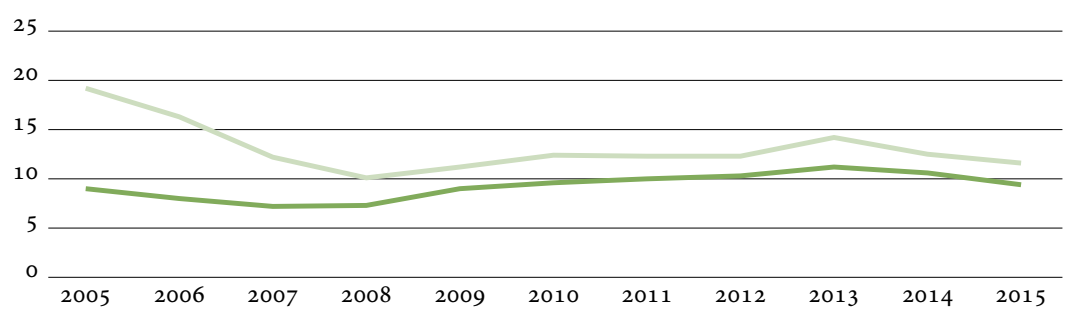

FIgURE 3 UE (Dark) and Poland (Light) Unemployment Rate (in percent) (based on data from https://pl.tradingeconomics.com)

However, this relatively high rate of growth is achieved with reference to the specific Polish economy situation. Poland is still an emerging and not mature economy. Polish GDP growth is accompanied by a high unemployment rate and low GDP per capita. Although after 1990 Poland started to reconstruct its economy into a market one, in the early 2000 
there were still a lot of problems to be solved. The GDP per capita is presented in figure 2 and the unemployment rate is presented in figure 3.

Although Poland seems to be barely affected by the financial crisis, it is still not a mature economy and capital structure decisions are still vulnerable to economic conditions. Due to the financial crisis and growing uncertainty of economic conditions, the investors and consumers' optimism decreased. What is more, the financial crisis was connected with more restrictive bank lending policy.

\section{Data}

Four sets of data were collected. The first set refers to aggregated financial data for the non-financial companies ( $\mathrm{NCF}$ ) of the whole economy. The data come from statistical books of Central Statistical Office of Poland. There are app. 50 thousand companies obliged to report to the Statistical Office and Statistical Office presents aggregated data. The data are available for the period of 2005-2016. However, because the data on the whole economy are aggregated and do not allow to execute a more thorough analysis, the second set of data was collected.

The second set of data consists of panel sample of non-financial companies (NCF) from the Warsaw Stock Exchange. The sample is selected by using the following criteria: firms are listed on the wSE for the whole period of 2005-2016 and firms operate in a non-financial sector. The financial data were hand collected from financial statements of each company. The relevant financial statements are extracted from Notoria Service/Emis. The financial data cover the period of 2005-2016. Companies with negative equity value and losses at the same time were eliminated to avoid obtaining a misleading positive ROE. Finally, the panel sample was designed with 2052 observations (year-company) for panel data of listed companies (12 years and 171 companies).

The third and fourth set of data consist of data from panel sample. Following Iqbal and Kume (2014), the companies with the highest and lowest debt ratio were identified and the sample was divided into two subsamples depending on the level of debt ratio. The first subsample contains the first percentile of the companies with the lowest debt ratio in the first year of the analysis (2005) - panel A, the second one contains the last percentile of the companies with the highest debt ratio in the first year of the analysis (2005) - panel B. This study further investigates the changes in leverage ratios of the sample firms and regression analysis by classifying them into two subsamples based on whether their pre-crisis 
leverage ratios place them in the first - panel A or the last percentile panel B.

\section{Methodology}

In every paper referring to the capital structure, the different methodologies of calculating leverage were implemented. In this study, the methodology of Rajan and Zingales (1995) was employed in calculating the debt ratio - the relation of total liabilities to total assets.

The analysis was conducted in two steps. The first step of the analysis is based on aggregated data for the companies of the whole economy. In addition, there are limited opportunities to conduct a more thorough analysis on the aggregated data. That is why the second step was taken, and the second step refers to panel firm-level data of the listed companies.

Because the aim of the paper is to identify whether there are any changes in the capital structure over time, especially pre-crisis, crisis and post-crisis time, it is necessary to decide on the years included in each sub period. There are different classification of crisis years (Henry and Gregoriou 2014; Wawryszuk-Misztal 2015). The idea of Iqbal and Kume (2014) was adopted who identified the 2006-2007 period as the pre-crisis period, 2008-2009 as the crisis period and 2010 and 2011 as the post-crisis period. To make it possible to compare the debt ratios for each period, the average debt ratios for each period were calculated.

For each pair of periods statistical tests were implemented to find out whether the ratios differ from each other. The study employs statistics tests for the difference in means (assuming unequal variances) to identify if equally-weighted mean leverage ratios are significantly different from each other during the three periods, namely 'pre-crisis to crisis', 'crisis to post-crisis', and 'pre-crisis to post-crisis.' However, before implementing the testing in changes of mean the normality test of the data distribution was assessed. To assess the normality of the sample Shapiro Wilk normality test was implemented. Depending on the results of Shapiro Wilk, normality test parametric or nonparametric test for the differences will be implemented.

In the paper, multivariate regression analysis was also implemented to try to find out the most important factor affecting capital structure decisions in each distinguished period. This paper also examines the impact of the financial crisis on firms' leverage ratios in a more formal setting. The dependent variable is the leverage ratio (LEV) calculated as the relation between total liabilities and total assets. The independent variables 
are the factors affecting capital structure (Bauer 2004; Titman and Wessels 1988; Korajczyk and Levy 2003; Cook and Tang 2010) such as profitability, tangibility and size. Panel data ols regression model is used, including pre-crisis, crisis and post-crisis dummies, to capture the impact of the financial crisis. The model also controls for other firm-specific factors that may have an impact on leverage ratios, as suggested by Titman and Wessels (1988) and many other researchers followed them:

$$
\begin{aligned}
\text { LEV }= & \beta_{\mathrm{O}}+\beta_{1} \text { Tangibility }_{i t}+\beta_{2} \text { Profitability }_{i t}+\beta_{3} \text { Size }_{i t} \\
& +\beta_{4} \text { PRE }+\beta_{5} \text { CRISIS }+\beta_{6} \text { POST }+u_{i}+e_{i t} .
\end{aligned}
$$

Fixed assets are estimated as the difference between total and shortterm assets; business profitability (Profitability) is return on assets (ROA) and is estimated as the net income divided by total assets; the firm's size (Size) is defined as the natural logarithm of firm's total assets; pre-crisis period (PRE) is represented by a dummy variable that takes a value of 1 for the years 2006 and 2007 and zero for other years, the crisis period (CRISIS), the main variable of interest, in the regression model is represented by a dummy variable that takes a value of 1 for years 2008 and 2009 and zero for other years; post-crisis period dummy (POST) variable takes the value of 1 for years 2010 and 2011 and zero for the other years in the analysed period.

The research is done for each set of data: the aggregated data of all the companies, panel sample and two subsamples. Only the firm-level data (from the panel sample and the subsamples) allow conducting statistical testing and a regression analysis.

\section{Research Findings}

The debt ratios are presented separately for each year with respect to the all non-financial companies of the whole economy and panel sample sand subsamples. The ratios for the sample and subsamples are presented by using mean and median value for each year. The basic statistics of debt ratio for the 2005-2016 period are presented in table 1.

After presenting descriptive statistics, a more thorough analysis was conducted. Shapiro-Wilk normality test was implemented to identify whether the data come from normal distribution. The null-hypothesis of this test is that the population is normally distributed. Thus, after having got the $p$-value o.ooo, which is less than the chosen alpha level, then the null hypothesis, is rejected and there is evidence that the data tested 
TABLE 1 Statistics of Debt Ratios for the Companies of the Whole Economy and Panel Sample Data

\begin{tabular}{rrrrrrrrrrrrrr}
\hline & 2005 & 2006 & 2007 & 2008 & 2009 & 2010 & 2011 & 2012 & 2013 & 2014 & 2015 & 2016 \\
\hline$(1)$ & 39.7 & 39.4 & 37.6 & 39.5 & 38.6 & 38.3 & 40.1 & 39.1 & 40.0 & 40.4 & 40.3 & 41.5 \\
\hline$(2)$ & 53.6 & 50.8 & 47.8 & 52.8 & 50.2 & 50.0 & 52.5 & 51.0 & 51.2 & 52.3 & 56.0 & 57.8 \\
& 53.2 & 51.4 & 48.7 & 48.2 & 46.7 & 47.5 & 49.5 & 48.7 & 47.1 & 47.9 & 48.3 & 52.8 \\
\hline$(3)$ & 24.2 & 28.9 & 35.2 & 37.9 & 33.6 & 32.1 & 35.7 & 34.4 & 28.7 & 30.8 & 33.5 & 34.7 \\
& 23.3 & 24.5 & 32.5 & 37.4 & 33.2 & 29.1 & 31.6 & 33.8 & 28.9 & 30.4 & 34.1 & 31.8 \\
\hline$(4)$ & 95.1 & 71.9 & 60.0 & 60.8 & 61.4 & 62.4 & 62.5 & 62.1 & 62.7 & 63.0 & 62.9 & 62.8 \\
& 84.0 & 74.5 & 57.5 & 61.7 & 61.2 & 64.8 & 64.0 & 67.7 & 64.2 & 66.1 & 64.4 & 59.3 \\
\hline
\end{tabular}

NOTES Row headings are as follows: (1) debt ratio percentage for the whole economy, (2) debt ratio percentage for panel data (mean and median), (3) debt ratio - panel A, (4) debt ratio - panel B.

TABLE 2 The Differences in the Debt Ratios in Sub Periods

\begin{tabular}{lllllll}
\hline Item & \multicolumn{2}{c}{$\begin{array}{c}\text { Pre-crisis } \\
\text { and crisis }\end{array}$} & \multicolumn{2}{c}{$\begin{array}{c}\text { Crisis and } \\
\text { post-crisis }\end{array}$} & \multicolumn{2}{c}{$\begin{array}{c}\text { Pre-crisis and } \\
\text { post crisis }\end{array}$} \\
\hline Debt ratio - sample & -0.050 & $(0.960)$ & -0.850 & $(0.396)$ & -0.299 & $(0.765)$ \\
Debt ratio - subsample A & $-2.082^{* *}$ & $(0.037)$ & -0.131 & $(0.896)$ & $-1.857^{*}$ & $(0.063)$ \\
Debt ratio - subsample B & -1.194 & $(0.232)$ & -0.231 & $(0.817)$ & -1.013 & $(0.311)$ \\
\hline
\end{tabular}

NOTES $\quad{ }^{*}{ }^{* *},{ }^{* *}$ significant at $10,5,1$ percent levels, respectively; $p$-values are in parentheses.

are not from a normally distributed population; in other words, the data are not normal. The parametric test cannot be implemented to compare any changes.

The study employs the nonparametric Wilcoxon tests for the differences in means to identify if the capital structure (and other) ratios are significantly different from each other during the three periods. The null hypothesis was that the mean is similar in the analysed periods. Each pair of analysed periods namely 'pre-crisis to crisis', 'crisis to post-crisis,' and 'pre-crisis to post-crisis' was compared. If the $p$-value is lower than alpha 0.1 , then the null hypothesis is rejected and there is evidence that the levels of ratios are similar. The statistics and $p$-value of Wilcoxon test are included in table 2.

The value of total assets for the companies of the whole economy grew by $75 \%$ between 2005 and 2011 and by $160 \%$ between 2005 and 2016 . It means that Polish companies developed their business quite heavily. The value of total debt grew by $80 \%$ between 2005 and 2011 and $170 \%$ between 
2005 and 2016. The growth rate of total liabilities is higher than total assets and that is why the debt ratio increased over the 2005-2016 period. The debt ratio was in 2005 lower than $40 \%$ and it got lower in 2007 because of the high profitability of Polish companies and growing value of the equity and the equity ratio. In 2009 and 2010, the impact of financial crisis on the debt ratio is visible. The companies lowered the debt ratios because it was more difficult for them to get bank financing. However, since 2011 the debt ratio is growing slowly.

For the panel sample, the average value of total assets grew by $160 \%$ between 2005 and 2011. This proves that Polish listed companies from panel sample developed their business intensively. The debt ratio for the panel sample of listed companies was in 2007 lower than in 2005 because of relatively high profitability and increase in equity value. The value of equity grew faster than total liabilities and the debt ratio decreased. However, since 2008 the debt ratio was kept at a stable level. The rapid growth in the level of the debt ratio is visible since 2014. Keeping a stable level of debt ratio and growing value of total assets means the value of total liabilities grew at the same pace as total assets. Although the changes in the debt ratio for the sample were visible, no statistically significant differences were identified over 2006-2011 (the low Wilcoxon tests value). It is because there were small changes (increase in crisis and post-crisis in relation to pre-crisis) in the debt ratio.

The average value of total assets for the companies from panel A was 116 mil PLN in 2005 and 477 mil PLN (4 times higher) in 2011 and 400 mil PLN in 2016. It means that, despite the crisis, companies were developing the business but only until 2011. Later the growth rate slowed down. It might mean the delayed effects of the financial crisis. The debt ratio for panel A grew since 2005 until 2008 but later in 2009 decreased and was kept at this low level until 2016. The increasing level of the debt ratio connected with growing total assets means that the value of total liabilities increased rapidly, faster than the equity value. After 2011 the development growth rate got slower. In addition, the debt ratio remained stable. This might mean a delayed impact of the financial crisis on the capital structure. For panel A the changes over 2006-2011 were bigger in the crisis and post-crisis period comparing to pre-crisis period ( $p$-value lower than o.1). There were statistically significant changes in pre-crisis debt ratio in relation to crisis and post crisis. The debt ratio was the lowest in pre-crisis and then during crisis it increased and after crisis was kept at stable level. 
TABLE 3 Descriptive Statistics of Factors Affecting Debt Ratio

\begin{tabular}{llrrrrr}
\hline Category & Factor & Mean & Median & Min & Max & SD \\
\hline Sample & Debt ratio (\%) & 52.12 & 49.00 & 1.00 & 99.00 & 32.60 \\
& Size (mil PLN) & 24,518 & 325 & 310 & $4,766,207$ & 280,833 \\
& Profitability (\%) & 3.39 & 4.24 & -18.90 & 24.70 & 15.70 \\
& Tangibility (\%) & 49.14 & 49.05 & 0.01 & 99.00 & 21.76 \\
\hline Panel A & Debt ratio (\%) & 32.42 & 30.35 & 4.00 & 96.00 & 15.37 \\
& Size (mil PLN) & 709 & 282 & 23 & 3,550 & 825 \\
& Profitability (\%) & 5.17 & 5.99 & -18.90 & 23.00 & 17.25 \\
& Tangibility (\%) & 58.79 & 59.25 & 0.01 & 99.0 & 20.23 \\
\hline Panel B & Debt ratio (\%) & 65.70 & 66.67 & 8.00 & 99.00 & 21.38 \\
& Size (mil PLN) & 1,226 & 544 & 12 & 2,700 & 3,064 \\
& Profitability (\%) & 1.64 & 2.48 & -15.00 & 42.00 & 13.96 \\
& Tangibility (\%) & 38.19 & 34.33 & 0.01 & 95.00 & 24.96 \\
\hline
\end{tabular}

NOTES $\quad *,{ }^{* *},{ }^{* *}$ significant at $10,5,1$ percent levels, respectively; $p$-values are in parentheses.

The average value of total assets for companies from panel B was 207 mil PLN in 2005, while 713 mil PLN in 2011 (more than 3 times higher) and 1,070 mil PLN in 2016. It means that companies were developing their business despite the crisis. As for leverage for the companies from panel B, different pattern is present. The debt ratio was highest in 2005 and since then it started a systematical decrease and the debt ratio in 2007 got the level by more than 20 percentage point was lower. Since 2007 , the debt ratio started to increase slowly. It means that companies development was financed by a growing value of the equity. As for period 20062011 for panel B, there were no statistically significant changes although there were small downward trend in debt ratio.

The next step of the analysis is to find factors affecting the debt ratio. Some factors were chosen such as profitability, tangibility, size and proxy for crisis. The descriptive statistics of the chosen factors were prepared and presented in table 3 . The companies from panel A seems to be smaller, more profitable and they have higher tangibility than the companies from panel $\mathrm{B}$. This might imply that the debt ratio is negatively related with profitability and tangibility but positively with size.

To find out how the factors (profitability, tangibility, size but also the crisis) a regression analysis was conducted. The regression analysis results were presented in table 4 . Profitability is negatively related for the sample 
TABLE 4 Regression Analysis Results

\begin{tabular}{lclllll}
\hline Item & \multicolumn{2}{c}{ Sample } & \multicolumn{2}{c}{ Panel A } & \multicolumn{2}{c}{ Panel B } \\
\hline Profitability & $-0.969^{\star * *}$ & $(0.000)$ & -0.078 & $(0.179)$ & $-0.528^{\star * *}$ & $(0.000)$ \\
Tangibility & $-0.213^{\star * *}$ & $(0.000)$ & $-0.173^{\star *}$ & $(0.003)$ & -0.076 & $(0.134)$ \\
Size & $0.014^{\star * *}$ & $(0.000)$ & $0.015^{\star *}$ & $(0.087)$ & $0.027^{\star *}$ & $(0.004)$ \\
Pre-crisis & $0.039^{\star *}$ & $(0.012)$ & $0.239^{\star *}$ & $(0.016)$ & 0.002 & $(0.369)$ \\
Crisis & $-0.069^{\star * *}$ & $(0.001)$ & $0.064^{\star *}$ & $(0.040)$ & $-0.166^{\star * *}$ & $(0.000)$ \\
Post-crisis & -0.022 & $(0.122)$ & 0.034 & $(0.154)$ & $-0.164^{\star * *}$ & $(0.000)$ \\
F-test & $113.738^{\star * *}$ & $(0.000)$ & $2.954^{\star *}$ & $(0.013)$ & $11.587^{\star * *}$ & $(0.000)$ \\
$R$-square & 0.218 & & 0.059 & & 0.200 & \\
\hline
\end{tabular}

NOTES ${ }^{*},{ }^{* *},{ }^{* *}$ significant at $10,5,1$ percent levels, respectively; $p$-values are in parentheses.

and subsamples. This is consistent with the previous research (González and González 2012; Rajan and Zingales 1995; Titman and Wessels 1988). The negative relation means that the higher profitability, the lower debt ratio which is consistent with the pecking order theory that assumes companies with higher profitability have lower debt ratios (Myers and Majluf 1984; Myers 1983). It seems that the crisis did not distort the pecking order preference and behaviour.

Our research points out that tangibility is also negatively related with the debt ratio, which is quite surprising because the theory and the previous research proved positive relation (e.g. Campello and Giambona 2010). A negative relation is present for the sample and subsamples. A negative relation was identified because companies with more fixed assets use more equity to finance them. Size and leverage are positively related (for the sample and subsamples) and it means that the bigger company, the higher debt ratio. This is consistent with the theory and the previous research (e.g. Rajan and Zingales 1995).

As for the impact of crisis on the debt ratio, the hypothesis assumed to find a positive relation between debt ratio and pre-crisis and post-crisis period and negative relation between the debt ratio and crisis period. The results are not confirming fully the expectations. The positive impact of pre-crisis period on debt ratio was found for the sample and subsamples. This means that in pre-crisis period companies were prone to increase debt ratios. However, the crisis had negative impact on the companies from the sample and from panel B, while for panel A the crisis had positive impact. This is consistent with the results of Wilcoxon test proving the changes in debt ratio in crisis period - increase for panel A and de- 
crease for panel B. The post-crisis period had negative impact on debt ratio for the sample and panel $\mathrm{B}$ - decrease in debt ratio while for panel A the positive impact was found - increase in debt ratio.

\section{Conclusions}

The aim of the paper was to identify changes in debt ratio during a financial crisis. The hypothesis was that the leverage would decrease during a crisis period and increase after a crisis. Financial data describing all companies in the whole economy (aggregated data) were employed and for research that is more thorough, a sample of listed companies (2052 observations) was designed. The analysis covered the period of 2005-2016.

The main finding of the study is that companies did not change significantly their capital structure. The debt ratio was similar during the whole period 2005-2016. It is especially true for the panel data and the companies with the highest debt ratio in 2005, but for the companies with the lowest debt ratio the financial crisis has positive impact on debt ratio. What is important, the financial crisis had some delayed impact on the debt ratio because the debt ratio was kept low long after the financial crisis was over.

The research results on the debt ratio changes contradict those, which identified the change in leverage, as argued by Fosberg (2012), Graham, Leary, and Roberts (2014) and Iqbal and Kume (2014). Especially, the drop in the debt ratio in our analysis was not as deep as in the mentioned research. In addition, the rise in debt ratio after crisis was not present. Polish economy and companies were not hit heavily by the crisis but the financial crisis had long-term impact on Polish economy. This might be proof that Polish economy still needs reforms. Managers of Polish companies are aware of specific situation of Polish economy. They try not to add extra financial risk to operating risk resulting from vulnerable and volatile economic situation.

But the analysis done for the purpose of the paper allows to raise more questions, e.g. what changes were in using bank loans during financial crisis, what changes were identified in the relation between long and short term capital during the financial crisis. It was also negative relation between tangibility and debt ratio identified and this makes a new research question and needs closer examination.

\section{References}

Al-Najjar, B., and B. K. Hussainey. 2011. 'Revisiting the Capital-Structure Puzzle: U K Evidence.' The Journal of Risk Finance 12 (4): 329-38. 
Baker, M., and J. Wurgler. 2002. 'Market Timing and Capital Structure.' Journal of Finance 57 (1): 1-32.

Baker, H. K., and G. S. Martin. 2011. Capital Structure and Corporate Financing Decisions: Theory Evidence and Practice. Hoboken, NJ: Wiley.

Bauer, P. 2004. 'Determinants of Capital Structure Empirical Evidence from the Czech Republic.' Czech Journal of Economics and Finance 54 (1-2): 2-21.

Campello, M., and E. Giambona. 2012. 'Real Assets and Capital Structure' NBER Working Paper 18147, National Bureau of Economic Research, Cambridge, MA.

Cook, D. O., and T. Tang. 2010. 'Macroeconomic Conditions and Capital Structure Adjustment Speed.' Journal of Corporate Finance 16 (1): 73-87.

Demirguc-Kunt, A., and M. S. Martinez-Peria, and T. Tressel. 2015. 'The Impact of the Global Financial Crisis on Firms' Capital Structure: The Role of Financial Markets and Institutions.' Policy Research Working Paper Series 7522, World Bank, Washington, DC.

Fosberg, R. H. 2012. 'Capital Structure and the Financial Crisis.' Journal of Finance and Accountancy 10:1-10.

González, V. M., and F. González. 2012. 'Firm Size and Capital Structure: Evidence Using Dynamic Panel Data.' Applied Economics 44 (36): 474554.

Graham, J. R., T. M. Leary, and M. R. Roberts. 2014. 'A Century of Capital Structure: The Leveraging of Corporate America.' NBER Working Paper 19910, National Bureau of Economic Research, Cambridge, MA.

Hackbarth, D., and Miao, J., and Morellecc, E. 2006. 'Capital Structure, Credit Risk, and Macroeconomic Conditions.' Journal of Financial Economics 82:519-50.

Harris, M., and A. Raviv. 1999. 'The Theory of Capital Structure.' Journal of Finance 46:297-355.

Henry S., and G. Gregoriou. 2014. 'IP O Firm Characteristics Pre- and PostFinancial Crisis.' Academy of Accounting and Financial Studies Journal 18 (2): $67-76$.

Iqbal, A., and O. Kume. 2014. 'Impact of Financial Crisis on Firms' Capital Structure in U K, France, and Germany'. Multinational Finance Journal $18(3-4): 249-80$.

Kahle, K., and R. Stulz. 2013. 'Access to Capital, Investment, and the Financial Crisis.' Journal of Financial Economics 110 (2): 280-99.

Korajczyk, R., and A. Levy. 2003. 'Capital Structure Choice: Macroeconomic Conditions and Financial Constraints.' Journal of Financial Economics 68 (1): 75-109.

Kraus, A., and R. H. Litzenberger. 1973. 'A State-Preference Model of Optimal Financial Leverage.' Journal of Finance 28 (4): 911-22. 
Modigliani, F., and M. H. Miller. 1958. 'The Cost of Capital, Corporate Finance and the Theory of Investment.' American Economic Review 48:261-97.

- 1963. 'Corporate Income Taxes and the Cost of Capital: A Correction.' American Economic Review 53:433-43.

Mostarac, E., and S. Petrovic. 2013. 'Determinants of Capital Structure of Croatian Enterprises Before and During the Financial Crisis.' UTMS Journal of Economics 4 (2): 153-62.

Myers, S. C. 1983. 'The Capital Structure Puzzle.' The Journal of Finance 39:575-92.

Myers, S. C., and N. S. Majluf. 1984. 'Corporate Financing and Investment Decisions When Firms Have Information That Investors Do Not Have.' Journal of Financial Economics 13 (2): 187-221.

OECD. 2013. 'The Economic Crisis and Recovery in OECD Regions and Cities.' https://www.oecd.org/regional/ministerial/Monitoring-the -Crisis.pdf

Pattani, A., G. Vera, and J. Wackett. 2011. 'Going Public: u K Companies' Use of Capital Markets.' Bank of England Quarterly Bulletin 51 (4): 31930.

Polanski, Z. 2014. 'Poland During the Crisis: A “Green Island” Approaching the Euro Area?' In Poland and the Eurozone: Studies in Economic Transition, edited by J. Hölscher, 165-95. London: Palgrave Macmillan.

Rajan, R. G., and L. Zingales. 1995. 'What Do We Know about Capital Structure? Some Evidence from International Data.' Journal of Finance 50:1421-60.

Titman, S., and R. Wessels. 1988. 'The Determinants of Capital Structure Choice.' Journal of Finance 43 (1): 1-19.

Wawryszuk-Misztal, A. 2015. 'Bezpośrednie koszty emisji akcji w pierwszej ofercie publicznej na GPW w Warszawie.' Prace Naukowe Uniwersytetu Ekonomicznego we Wrocławiu 412, Wrocław.

This paper is published under the terms of the Attribution-

NonCommercial-NoDerivatives 4.o International (CC B Y-NC-ND 4.0)

License (http://creativecommons.org/licenses/by-nc-nd/4.o/). 